\title{
SISTEM INFORMASI PENDAFTARAN UJI KOMPETENSI PADA LEMBAGA SERTIFIKASI PROFESI PERTANIAN ORGANIK JAKARTA
}

\author{
Abdul Hamid1 ${ }^{1)}$, Ali Martondi ${ }^{2)}$, Syamsul Bahri ${ }^{3)}$, Lukman Hakim ${ }^{4)}$ \\ Numan Musyaffa ${ }^{5)}$, Ricki Sastra) \\ ${ }^{1,6}$ Teknologi Informasi,Universitas Bina Sarana Informatika Jakarta \\ ${ }^{3,4}$ Ekonomi dan Bisnis, Universitas Bina Sarana Informatika Jakarta \\ ${ }^{2,5}$ STMIK Nusa Mandirin Jakarta \\ email: hamid.adh@bsi.ac.id
}

\begin{abstract}
Abstrak: Pelaksanaan pendaftaran uji kompetensi secara konvensional atau offline, yaitu dengan mendatangi kantor dari lembaga sertifikasi pertanian organik yang belum tersedia di banyak kota sangatlah tidak efektif. Selain membutuhkan waktu yang luang, pendaftaran secara konvensional juga membutuhkan biaya tambahan dari yang semestinya, baik biaya perjalanan maupun biaya operasional lainnya. Di zaman seperti sekarang, dimana teknologi semakin berkembang dan merambat ke berbagai pelosok negeri, secara tidak langsung kita sebagai manusia di tuntut untuk melakukan sesuatu dengan profesional, tepat waktu dan tidak bertele-tele sehingga waktu yang tersisa bias dimanfaatkan untuk kegiatan yang lain. Oleh sebab itu, diharapkan adanya sebuah sistem yang dapat memudahkan pelaksanaan pendaftaran uji kompetensi tersebut, salah satunya adalah dengan memanfaatkan sistem informasi maupun website, sehingga pendaftaran yang tadinya dilakukan secara offline dirubah menjadi online. Sistem informasi pendaftaran uji kompetensi memungkinkan calon peserta uji kompetensi dapat melakukan pendaftaran secara online. Sistem informasi pendaftaran uji kompetensi merupakan sebuah website yang dibuat menggunakan bahasa pemrograman PHP dengan framework CodeIgniter 3.0, ditambah dengan tampilan yang dibuat menggunakan CSS dengan framework Botstrap 4.0. Perancangan system informasi ini menggunakan model pengembangan waterfall serta diagram UML (Unified Modelling Language) yaitu Use Case Diagram, Component Diagram dan Deployment Diagram.
\end{abstract}

Kata kunci: System, Informasi, Kompetensi

Abstract: The implementation of competency test registration conventionally or offline, namely by visiting offices of organic agriculture certification bodies that are not yet available in many cities is very ineffective. Besides requiring free time, conventional registration also requires additional costs than they should, both travel costs and other operational costs. In this day and age, where technology is increasingly developing and spreading to various corners of the country, we indirectly as humans are required to do something professionally, on time and not to beat around the bush so that the remaining time can be used for other activities. Therefore, it is expected that a system that can facilitate the implementation of the competency test registration, one of which is by utilizing information systems and websites, so that registration that was done offline was changed to online. The competency test registration information system enables prospective competency test participants to register online. The competency test registration information system is a website created using the PHP programming language with the CodeIgniter 3.0 framework, coupled with a display created using CSS with the Botstrap 4.0 framework. System planning. This information uses the waterfall development model and UML (Unified Modeling Language) diagram, namely Use Case Diagrams, Component Diagrams and Deployment Diagrams.

Keywords: System, Information, Competence

\section{PENDAHULUAN}

Setiap pekerjaan dibidang apapun di zaman teknologi seperti sekarang, para pekerja dituntut untuk dapat menyelesaikan pekerjaannya secara efektif, efisien dan akuntabel. Tenaga kerja yang profesional dan 
kompeten dibidangnya sangat dibutuhkan saat ini. Tenaga kerja yang kompeten juga dapat menjadi suatu langkah tercapainya mutu dan produktivitas maupun daya saing tenaga kerja yang diharapkan .

Menurut (Adhawiyah, Kumaladewi, \& CaturUtami, 2017) kompetensi merupakan suatu kemampuan untuk melaksanakan atau melakukan suatu pekerjaan atau tugas, yang dilandasi atas keterampilan dan pengetahuan, serta didukung oleh sikap kerja yang dituntut oleh pekerjaan tersebut

Ada banyak cara yang dapat dilakukan untuk memecahkan masalah tersebut,salah satunya adalah dengan melakukan sertifikasi kompetensi demi mendapatkan data yang valid secara autentik sebagai acuan apakah tenaga kerja tersebut sudah kompeten atau tidak di bidangnya masing-masing.

Menurut (Jatnika, 2016) sertifikasi kompetensi yaitu sertifikat kompetensi yang diberikan melalui uji kompetensi sesuai standar nasional.

Dengan adanya uji kompetensi, dalam hal ini sertifikasi profesi, banyak keuntungan yang didapat oleh kedua belah pihak, baik bagi penyedia lapangan pekerjaan maupun bagi calon tenaga kerja itu sendiri. Peserta uji kompetensi yang telah dinyatakan lulus berhak mendapat sertifikat dari pelaksana uji kompetensi, dimana sertifikat merupakan bukti tertulis bahwa peserta uji kompetensi tersebut telah diakui kompeten dibidangnya

Banyak lembaga yang menyediakan uji kompetensi di berbagai bidang tanpa terkecuali dibidang pertanian organik, baik dari perusahaan negeri maupun swasta dengan tujuan yang sama, salah satunya adalah Lembaga Sertifikasi Profesi Pertanian Organik. LSP Pertanian Organik adalah lembaga yang mendapatkan lisensi BNSP yang bergerak dan bertanggung jawab melaksanakan sertifikasi kompetensi profesi khususnya dibidang pertanian organik.

Penelitian pada LSP Pertanian Organik Jakarta tentang pelaksanaan uji kompetensi pada lembaga tersebut, tampak beberapa cara yang dilakukan masih menggunakan cara-cara yang konvensional, seperti melakukan pendaftaran dan penjadwalan serta penetapan tempat uji kompetensi.

Menurut (Adhawiyah et al., 2017) sistem merupakan kumpulan komponen-komponen yang bekerja sama untuk tujuan bersama. Misalnya bidang organisasi keuangan, operasi dan pemasaranmemiliki tujuan yang sama untuk mencapai tujuan perusahaan secara keseluruhan.

Menurut (Andalia \& Setiawan, 2015) sistem yaitu suatu gabungan elemen yang saling berinteraksi untuk mencapai tujuan.

Menurut (Asmara, 2016) sistem adalah kumpulan komponen atau subsistem yang saling terkait dan bekerja sama untuk mencapai suatu tujuan

Sebagai lembaga yang tujuannya memberikan sertifikasi terhadap calon tenaga kerja, sudah sepatutnya memanfaatkan teknologi yang ada. Seperti beralih dari cara yang konvensional ke cara yang lebih efisien, sehingga dapat menghemat tenaga dan waktu dalam pelaksanaannya. Dengan menggunakan sistem informasi uji kompetensi juga dapat memudahkan para calon peserta untuk mengakses informasi tanpa harus mendatangi kantornya sekalipun.

\section{METODE PENELITIAN}

Ada beberapa teknik pengumpulan data sebagai berikut: 1. Observasi (melakukan penelitian dengan cara terjun

kelapangan serta mengamati secara langsung proses pelaksanaan uji kompetensi, mulai dari pengisian formulir pendaftaran, proses ujian tulis maupun praktikum, sampai tahap pengumuman disertai dengan penyerahan sertifikat bagi peserta yang telah dinyatakan lulus, 2. Wawancara langsung dengan narasumber yaitu Bapak Agus Yulianto selaku wakil Direktur pada Lembaga Sertifikasi Profesi Pertanian Organik yang memegang wewenang dalam pelaksanaan uji kompetensi, 3. Referensi untuk mendapatkan data yang valid; mencari dari berbagai judul buku, jurnal, serta website resmi yang berkaitan dengan perancangan sistem informasi seperti definisi dan penerapannya kedalam sebuah sistem.

\section{HASIL DAN PEMBAHASAN Prosedur Pendaftaran}

LSP Pertanian Organik melakukan promosi melalui berbagai media, baik media cetak maupun digital. Media cetak berupa brosur yang menyertakan alamat perusahaan, kontak perusahaan dan biaya sertifikasi. Bagi calon peserta yang ingin mengikuti uji kompetensi dapat langsung mendatangi kantor LSP Pertanian Organik yang beralamat di Gedung 
Hortikultura, Jl. AUP No.3, Pasar Minggu, Jakarta Selatan.

Calon peserta akan menerima formulir dari admin perusahaan, serta beberapa persyaratan lainnya. Setelah peserta mengisi formulir dan memenuhi persyaratan yang diminta, calon peserta kembali menyerahkan formulir kepada admin perusahaan, lalu admin menyerahkan dokumen tersebut kepada Manager Sertifikasi untuk ditinjau lebih lanjut. Bagi calon peserta yang memenuhi persyaratan akan menerima surat konfirmasi pendaftaran, kemudian dilanjutkan dengan mengisi formulir kedua serta beberapa dokumen lainnya. Setelah semua terpenuhi maka calon peserta dinyatakan sah sebagai peserta uji kompetensi.

Tabel 1. Tabel Activity Diagram Pendaftaran Prosedur Pelaksanaan Ujian Kompetensi

\begin{tabular}{|c|c|c|}
\hline \multicolumn{3}{|c|}{ Activitv Diagram Pendaftaran } \\
\hline Calon Peserta & Admin & Manager \\
\hline Mendaftar & Membagikan & Tinjau \\
\hline Mengisi & Formulir1 & Permohona \\
\hline Formulir & Verifikasi & $\mathrm{n}$ \\
\hline Meneria Surat & Data & Diterima? \\
\hline$\&$ & Membuat & \\
\hline Formulir2 & Surat & \\
\hline Mengisi & Keterangan & \\
\hline Formulir2 & $\underline{\text { Diterima }}$ & \\
\hline Melakukan & Verifikasi Data & \\
\hline Pembayaran & $\&$ & \\
\hline Terima Jadwal & Pembayaran & \\
\hline
\end{tabular}

Peserta yang telah terdaftar sebagai anggota uji kompetensi akan mendapat jadwal ujian serta Tempat Uji Kompetensi (TUK). Tempat Uji Kompetensi (TUK) disesuaikan dengan kota masing-masing peserta.

Ujian dilaksanakan dengan metode praktikum yang langsung diawasi dan nilai oleh Manager Sertifikasi. Ujian dilaksanakan di kampus yang telah bekerja sama dengan LSP Pertanian Organik.

Bagi peserta yang dinyatakan lulus akan diberikan sertifikat sebagai bukti telah kompeten di bidangnya, bagi yang peserta belum lulus dapat mengikuti ujian ulang maksimal satu kali. Pengumuman hasil ujian dapat diperoleh selambat-lambatnya satu minggu setelah ujian berakhir. Berikut activity diagram dari prosedur tersebut:
Tabel 2. Tabel Activity Diagram Uji Kompetensi

\begin{tabular}{|c|c|}
\hline Activity Diagram Uji Kompetensi \\
\hline Peserta & Manager Sertifikasi \\
\hline Mengikuti Ujian & Mengawasi Ujian \\
Remedial & Lulus? \\
Mendapat & Ya \\
Sertifikat & Ujian Selesai \\
\hline
\end{tabular}

\section{Tahapan Analisa}

Tahapan analisa merupakan sebuah tahapan yang bertujuan untuk mendapatkan data maupun informasi tentang spesifikasi perangkat lunak yang dibutuhkan oleh pengguna. Keterlibatan kedua belah pihak, baik pengguna maupun pembuat perangkat lunak sangat diharapkan dalam tahap ini. Sehingga pembuat perangkat lunak memiliki acuan dalam melakukan desain sesuai kebutuhan pengguna.

Dalam kasus ini, tahapan analisa yang dilakukan oleh penulis memiliki gambaran tentang sebuah aplikasi pendaftaran uji kompetensi berbasis web yang dapat menampilkan informasi dari perusahaan penyedia uji kompetensi, form untuk pendaftaran bagi calon peserta uji kompetensi, dan halaman administrator untuk mengelola data perusahaan, sehingga penulis dapat mengategorikan kebutuhan perangkat lunak dalam pembuatan aplikasi ini sebagai berikut: Halaman Calon Peserta Uji Kompetensi:

A1. Calon peserta dapat melakukan pendaftaran

A2. Calon peserta dapat melakukan konfirmasi pembayaran

Tampilan Halaman Admin:

B1 Admin dapat memverifikasi data peserta uji kompetensi

B2. Admin dapat mengonfirmasi pendaftaran

B3. Admin dapat mengelola data peserta uji kompetensi

B4. Admin dapat mengelola daftar judul sertifikasi

B5. Admin dapat mengelola profil

\section{Use Case Diagram}

Use Case Diagram merupakan gambaran grafis dari beberapa atau semua Actor, Use Case, dan interaksi yang bertujuan untuk memperkenalkan suatu sistem.

Use Case Diagram digunakan untuk memahami fungsi-fungsi yang terdapat di dalam sebuah sistem informasi. 
1. Use Case Diagram Halaman Calon/Peserta

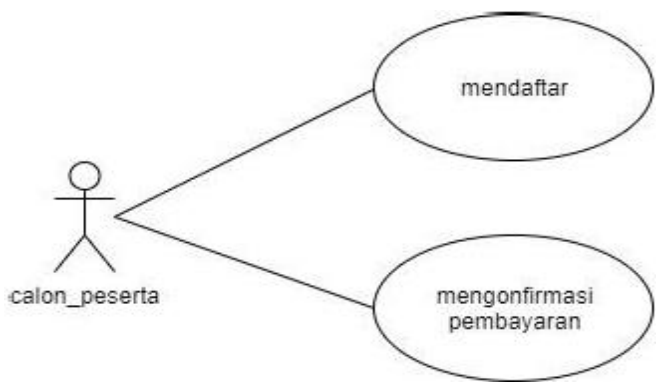

Gambar 1 Us Case Diagram Halaman Calon Peserta

Deskripsi Use Case Diagram halaman calon peserta uji kompetensi sbb :

Tabel 3. Tabel Deskripsi Us Case Diagram Calon Peserta

\begin{tabular}{|c|c|}
\hline Use Case Diagram & Pendaftaran \\
\hline Requirements & A1-A2 \\
\hline Goal & $\begin{array}{l}\text { Calon peserta dapat } \\
\text { melakukan pendaftaran }\end{array}$ \\
\hline Pre-conditions & $\begin{array}{l}\text { Calon peserta mengunjungi } \\
\text { website LSPO }\end{array}$ \\
\hline Post-conditions & $\begin{array}{l}\text { Calon peserta berhasil } \\
\text { melakukan pendaftaran }\end{array}$ \\
\hline Failed end conditions & $\begin{array}{l}\text { Calon peserta membatalkan } \\
\text { pendaftaran }\end{array}$ \\
\hline Primary Actor & Calon peserta \\
\hline Main Flow/Basic Path & $\begin{array}{l}\text { 1. Calon peserta dapat } \\
\text { melakukan pendaftaran } \\
\text { 2. Calon peserta dapat } \\
\text { mengonfirmasi }\end{array}$ \\
\hline Invariant $A$ & - \\
\hline
\end{tabular}

\section{Use Case Diagram Halaman Admin}

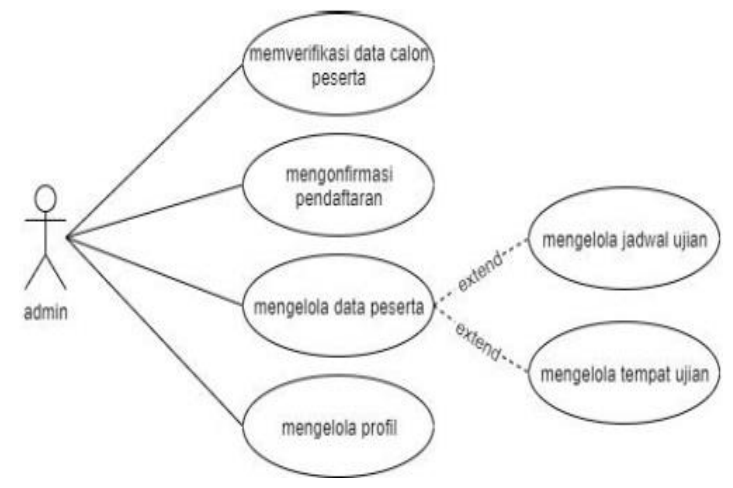

Gambar 2 Us Case Diagram Halaman Admin
Deskripsi Us Case Diagram halaman admin sbb :

Tabel 4. Tabel Deskripsi Us Case Diagram Halaman Admin

\begin{tabular}{|c|c|}
\hline Use Case Diagram & Mengelola halam admin \\
\hline Requirements & B1-B5 \\
\hline Goal & $\begin{array}{lll}\begin{array}{l}\text { Admin } \\
\text { website }\end{array} & \text { dapat mengelola } \\
\end{array}$ \\
\hline Pre-conditions & $\begin{array}{l}\text { Terhubung dengan web } \\
\text { server }\end{array}$ \\
\hline Post-conditions & $\begin{array}{lcc}\text { Admin dapat masuk } \\
\text { kehalaman }\end{array}$ \\
\hline Failed end conditions & Admin gagal login \\
\hline Primary Actor & Administrator \\
\hline Main Flow/Basic Path & $\begin{array}{l}\text { 1. Admin dapat } \\
\text { memverifikasi data aclon } \\
\text { peserta } \\
\text { 2. Admin dapat } \\
\text { menkonfirmasi } \\
\text { pendaftaran } \\
\text { 3. Admin dapat mengelola } \\
\text { data peserta } \\
\text { 4. Admin dapat mengelola } \\
\text { daftar judul sertifikasi } \\
\text { 5. Admin dapat mengelola } \\
\text { profile }\end{array}$ \\
\hline Invariant $B$ & - \\
\hline
\end{tabular}

\section{Desain}

Membuat sebuah sistem pendaftaran online uji kompetensi, tahapan desain dibutuhkan untuk menggambarkan beberapa desain dari sebuah website yang akan dibangun, meliputi desain tampilan antar muka, database manajemen, maupun desain software architecture, sehingga dengan tahapan desain diharapkan dapat memudahkan pembuat aplikasi dalam membangun sistem informasi sesuai dengan yang diharapkan

\section{Database}

Penulis menggunakan Entity Relationship Diagram (ERD) dalam pembuatan sistem informasi pendaftaran uji kompetensi kali ini, sehingga penulis dapat menggambarkannya sebagai berikut: 


\section{Entity Relationship Diagram}



Gambar 3 Entity Relationship Diagram

\section{Logical Record Structure}

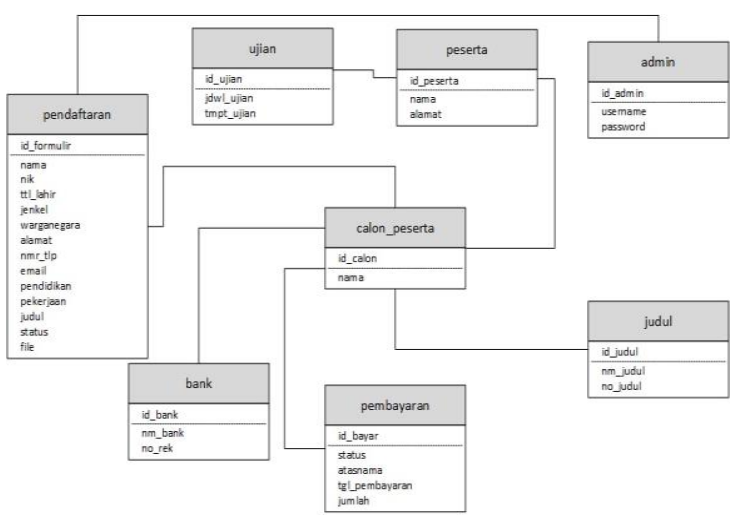

Gambar 4 Logic Record Structure Pendaftaran Uji Kompetensi

\section{Software Architecture}

Merupakan sebuah proses untuk mendefinisikan struktur dari suatu aplikasi yang meliputi seluruh kriteria dari sisi teknis dan juga operasional dari aplikasi tersebut, atau gambaran dari software dalam bentuk fisik sehingga dapat dipetakan.

\section{Class Diagra}

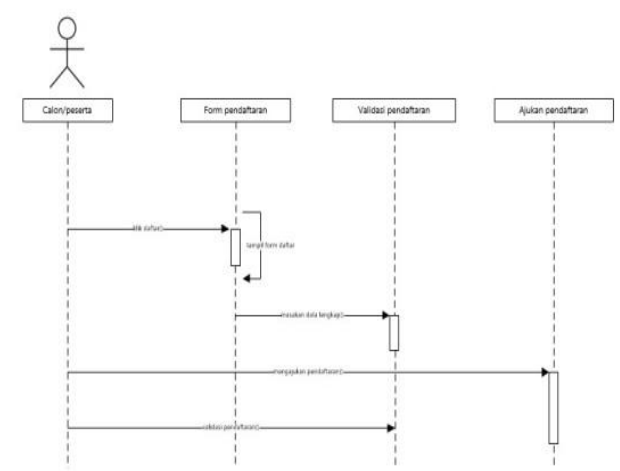

Gambar 5 Class Diagram
2. Sequence Diagram

a. Sequence Diagram Calon Peserta

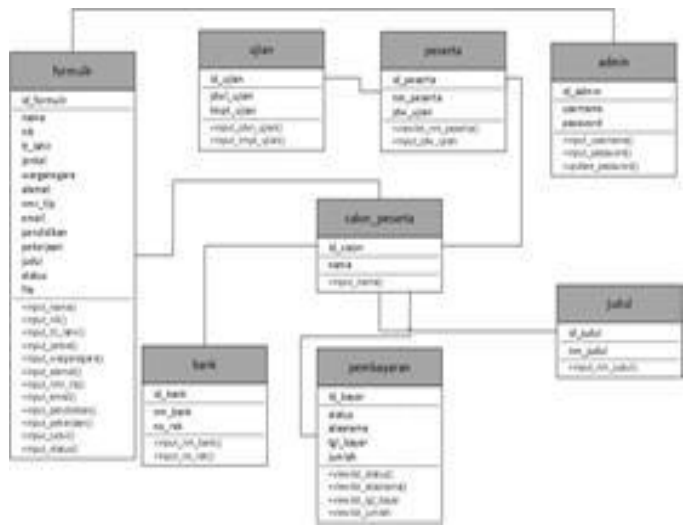

Gambar 6 Sequence Diagram Halaman Calon Peserta

b. Sequence Diagram Admin

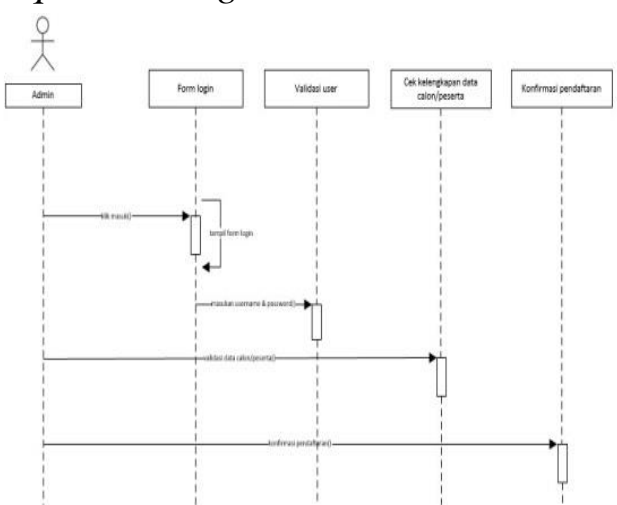

Gambar 7 Sequence Diagram Halaman Admin

\section{Component Diagram}



Gambar 8 Component Diagram 


\section{Deployment Diagram}

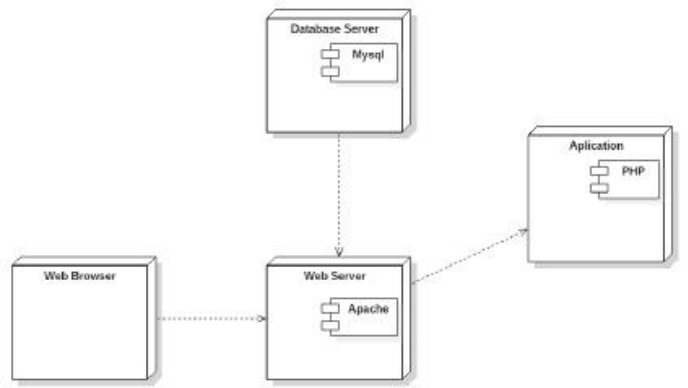

Gambar 9 Deployment Diagram

\section{User Interface}

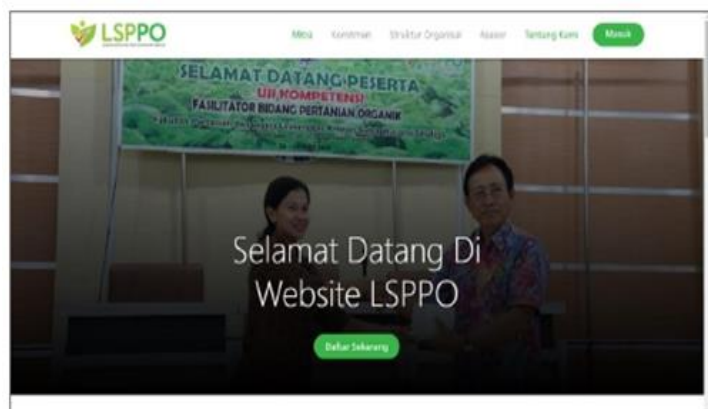

Gambar 10 Tampilan Halaman Home



Gambar 11 Tampilan Login Admin

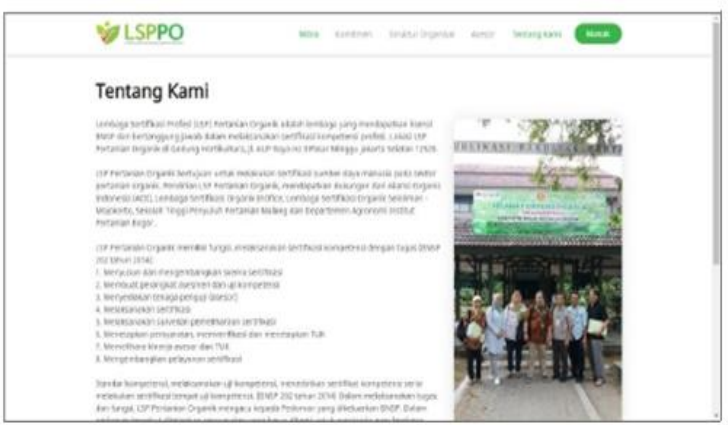

Gambar 12 Tampilan Tentang Kami

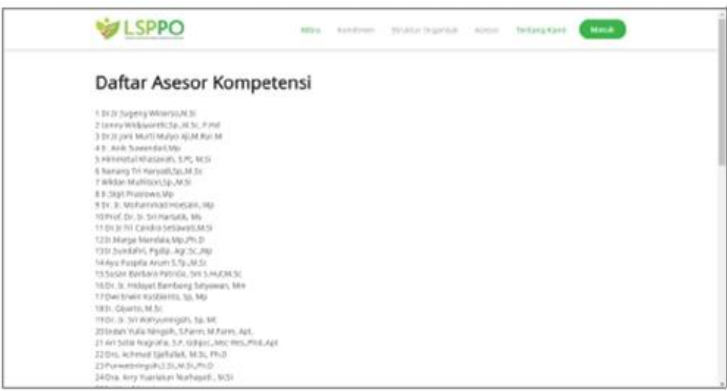

Gambar 13 Tampilan Halaman Daftar Asesor

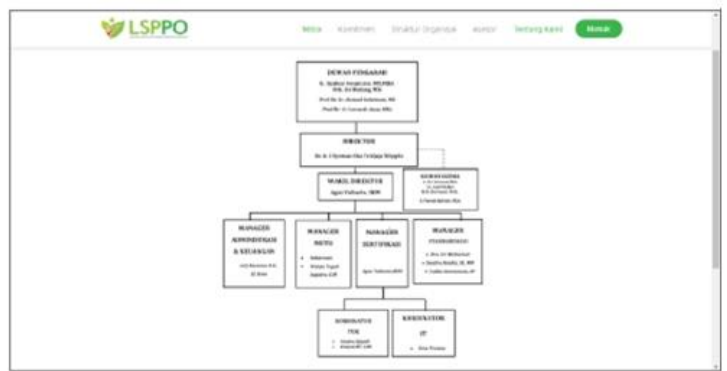

Gambar 14 Tampilan Halaman Organisasi

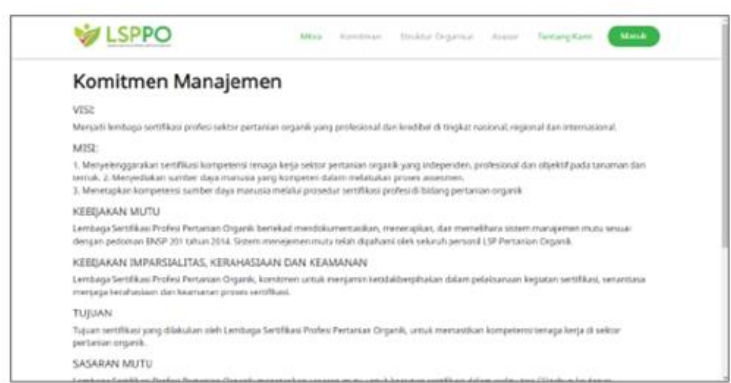

Gambar 15 Tampilan Halaman Komitmen

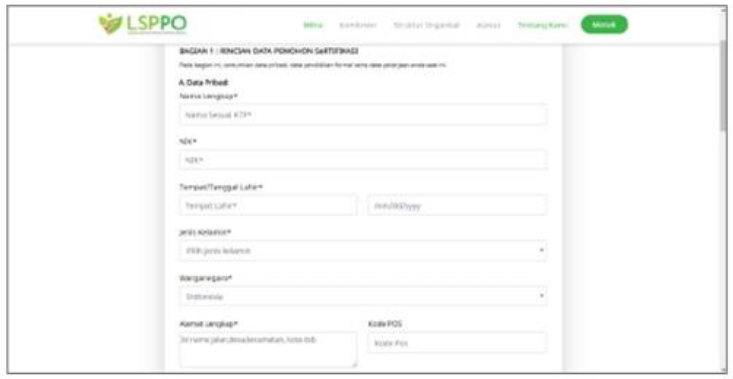

Gambar 16 Tampilan Halaman Pendaftaran

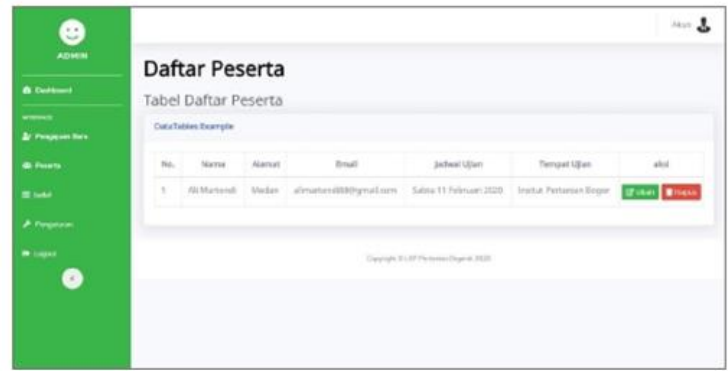

Gambar 17 Tampilan Halaman Daftar Peserta 


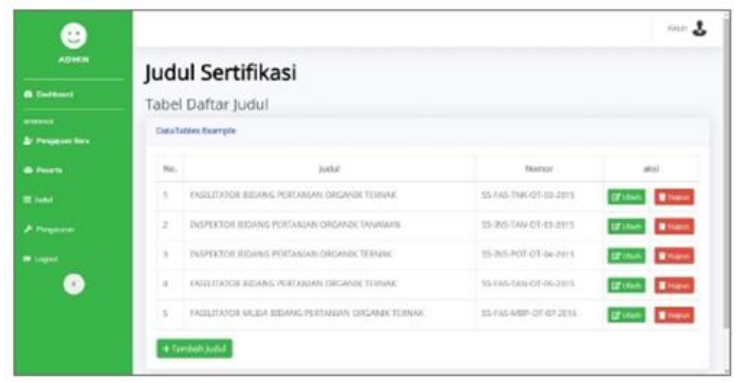

Gambar 18 Tampilan Halaman Judul

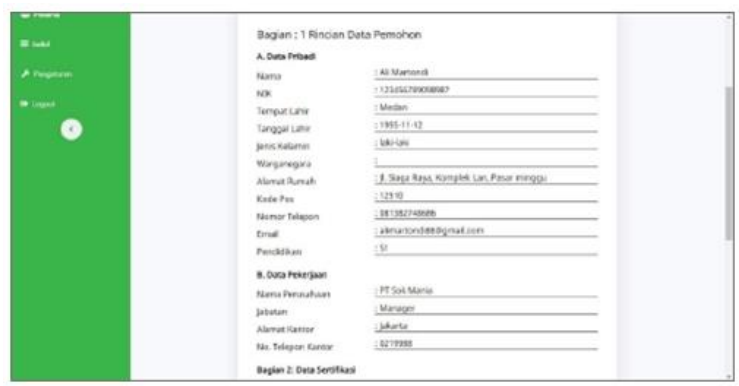

Gambar 19 Tampilan Halaman Detail Pengajuan

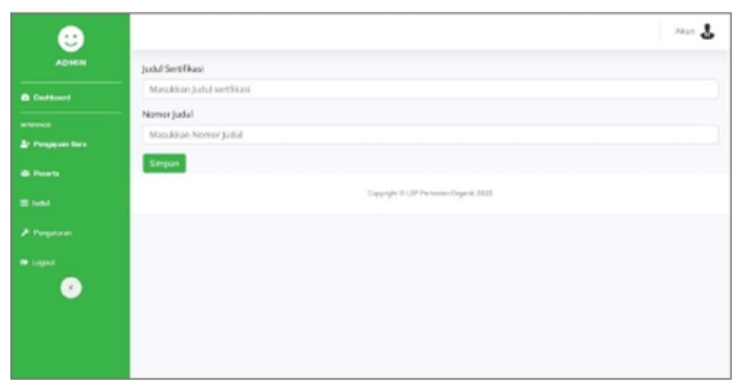

Gambar 20 Tampilan Halaman Tambah Judul

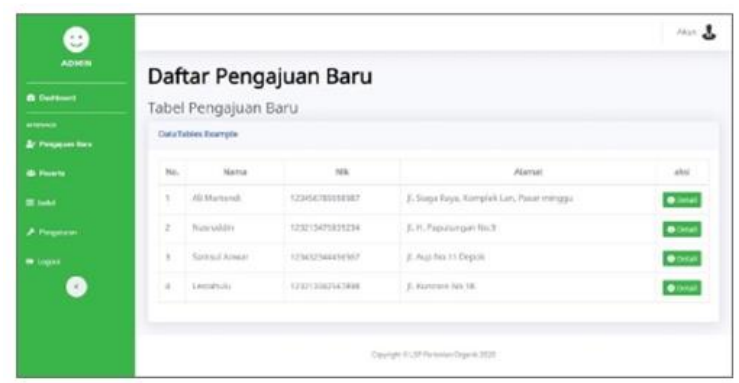

Gambar 21 Tampilan Halaman Pengajuan Baru

\section{Publikasi Web}

Untuk nama domain, penulis mendaftarkan domain website ini melalui www.hostinger.co.id yaitu salah satu web hosting yang cukup populer dikalangan para pembuat web untuk membangun website mereka. Domain yang penulis daftarkan yaitu lspopertanianorganik.com dengan kapasitas hosting 1GB. Dengan biaya hosting + domain sebesar 269.280 IDR selama satu tahun.

Penelitian ini sejalan dengan beberapa penelitian terdahulu yaitu (Suryani, 2016) mengemukakan bahwa perlu dilakukan perhitungan yang akurat untuk memprediksi peluang lulus mahasiswa yang mengikuti sertifikasi Microsoft dengan menggunakan Teori Roughset.

Selanjutnya penelitian (Murjana, 2015) yang berupa rancangan DFD, ERD, rancangan tabel, konseptual database dan rancangan user interface. Kemudian penelitian (Safitri, 2017) yang mengemukakan bahwa uji kompetensi dibutuhkan sebagai dasar tindak lanjut pembinaan dan untuk memetakan kompetensi yang dimiliki oleh karyawan.

\section{KESIMPULAN}

Uji kompetensi bertujuan untuk meningkatkan sumber daya manusia agar kompeten di bidangnya. Dengan adanya sistem informasi ini, dapat memudahkan para calon peserta uji kompetensi dalam melakukan pendaftaran uji kompetensi. Sistem informasi ini juga dapat memudahkan administrator dalam mengelola data peserta uji kompetensi.

\section{DAFTAR PUSTAKA}

Adhawiyah, Y., Kumaladewi, N., \& CaturUtami, M. (2017). Rancang Bangun Sistem Informasi Penilaian Kinerja Pegawai Menggunakan Metode Psycological Appraisal. Jurnal Sistem Informasi, 10(2), 119126.

Andalia, F., \& Setiawan, E. B. (2015). Pengembangan Sistem Informasi Pengolahan Data Pencari Kerja Pada Dinas Sosial Dan Tenaga Kerja Kota Padang. Jurnal Ilmiah Komputer Dan Informatika (KOMPUTA), 4(2), 9398. 
Asmara, R. (2016). Sistem Informasi Pengolahan Data Penanggulangan Bencana Pada Kantor Badan Penanggulangan Bencana Daerah (Bpbd) Kabupaten Padang Pariaman. Jurnal J-Click, 3(2), 80-91.

Jatnika. (2016). Perancangan Sistem Informasi Peserta Sertifikasi. PETIR (Jurnal Pengkajian Dan Penerapan Teknik Informatika), 9(2).

Murjana, I. G. M. (2015). Perancangan Aplikasi Sistem Infromasi Perhitungan Sertifikasi Guru Berbasis Web. Jurnal Sistem Dan Informatika, 10(1), 64-75.

Safitri, M. (2017). Sistem Aplikasi Uji Kompetensi Penerimaan Karyawan Berbasis Web. Information Management For Educators And Professionals, 1(2), 125-134.

Suryani, K. (2016). Prediksi Peluang Kelulusan Mahasiswa PTIK dalam Uji Kompetensi Microsoft Office 2010 menggunakan Teori Rough Set. Jurnal Nasional Teknologi Dan Sistem Informasi (TEKNOSI), 2(1), $1-10$. 